\title{
Wheat Blast in Bangladesh: The Current Situation and Future Impacts
}

\author{
M. Tofazzal Islam $\mathbb{1}^{1 *}$, Kwang-Hyung Kim² ${ }^{2}$ and Jaehyuk Choi $\mathbb{1 D}^{3 *}$ \\ ${ }^{I}$ Department of Biotechnology, Bangabandhu Sheikh Mujibur Rahman Agricultural University, Gazipur-1706, Bangla- \\ desh \\ ${ }^{2}$ Department of Climate Service and Research, APEC Climate Center, Busan 48058, Korea \\ ${ }^{3}$ Division of Life Sciences, College of Life Sciences and Bioengineering, Incheon National University, Incheon 22012, \\ Korea
}

(Received on August 21, 2018; Accepted on October 14, 2018)

Wheat blast occurred in Bangladesh for the first time in Asia in 2016. It is caused by a fungal pathogen, Magnaporthe oryzae Triticum (MoT) pathotype. In this review, we focused on the current status of the wheat blast in regard to host, pathogen, and environment. Despite the many efforts to control the disease, it expanded to neighboring regions including India, the world's second largest wheat producer. However, the disease occurrence has definitely decreased in quantity, because of many farmers chose to grow alternate crops according to the government's directions. Bangladesh government planned to introduce blast resistant cultivars but knowledges about genetics of resistance is limited. The genome analyses of the pathogen population revealed that the isolates caused wheat blast in Bangladesh are genetically close to a South American lineage of Magnaporthe oryzae. Understanding the genomes of virulent strains would be important to find target resistance genes for wheat breeding. Although the drier winter

*Co-corresponding authors.

Jaehyuk Choi

Phone) +82-32-835-8242, FAX) +82-32-835-0763

E-mail)jaehyukc@inu.ac.kr

ORCID

https://orcid.org/0000-0002-7865-2936

M. Tofazzal Islam

Phone) +88-0171-4001414, FAX) +88-02-920-5333

E-mail) tofazzalislam@yahoo.com

ORCID

https://orcid.org/0000-0002-7613-0261

(c) This is an Open Access article distributed under the terms of the Creative Commons Attribution Non-Commercial License (http:// creativecommons.org/licenses/by-nc/4.0) which permits unrestricted noncommercial use, distribution, and reproduction in any medium, provided the original work is properly cited.

Articles can be freely viewed online at www.ppjonline.org. weather in Bangladesh was not favorable for development of wheat blast before, recent global warming and climate change are posing an increasing risk of disease development. Bangladesh outbreak in 2016 was likely to be facilitated by an extraordinary warm and humid weather in the affected districts before the harvest season. Coordinated international collaboration and steady financial supports are needed to mitigate the fearsome wheat blast in South Asia before it becomes a catastrophe.

Keywords : disease control, genomics, India, Pyricularia oryzae, wheat blast

Handling Editor : Lee, Jungkwan

Increasing rate of emerging fungal diseases in crop plants is a serious threat to food and nutritional security of increasing population in the world (Fisher et al., 2012; Pennisi, 2010). One of the striking examples is the new emergence and re-emergence of blast disease which is caused by distinct pathotypes of a filamentous fungus Magnaporthe oryzae (Igarashi et al., 1986; Inoue et al., 2017). In February 2016, Bangladesh was reported as the first Asian country having an outbreak of worrisome wheat blast disease caused by a South American lineage of a hemibiotrophic filamentous fungus Magnaporthe oryzae Triticum (MoT) pathotype (Callaway, 2016; Islam et al., 2016; Malaker et al., 2016). Before that occurrence, wheat blast disease has been observed only in the countries in South America (Igarashi et al., 1986; Kohli et al., 2011) and in a single spike of wheat in an experimental plot in Kentucky in the USA (Farman et al., 2017). Through the first emergence in Bangladesh, the wheat blast entered into Asia which is the 

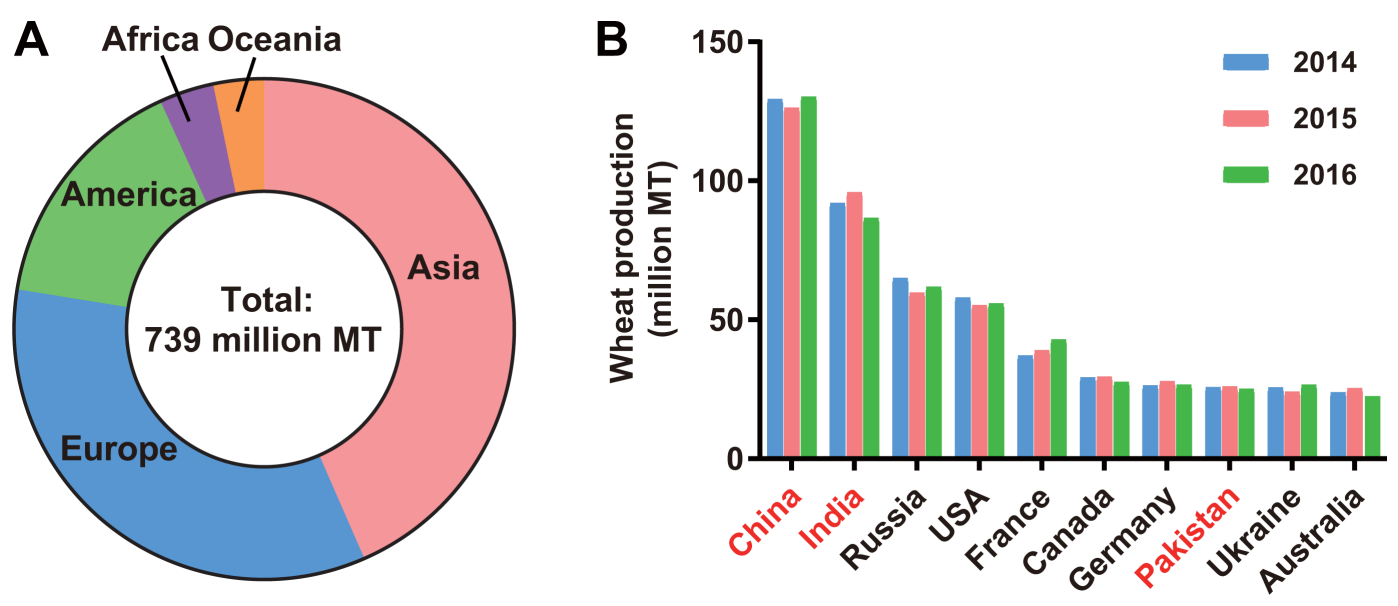

Fig. 1. World wheat production. (A) World wheat production by continents. Average values during 2014-2016 were used for the graph. (B) Top ten wheat producing countries. All data were obtained from FAOSTAT (http://www.fao.org/faostat/en/\#data/QC).

ground for about $42 \%$ of the world wheat production (Fig. 1A). In Asia, China, India, and Pakistan, among the world top ten wheat producing countries, are next door to Bangladesh (Fig. 1B). Earlier, we reported on the cause and origin of the first emergence of wheat blast in Bangladesh and expressed our concerns over its possible consequences in Asian wheat production and food security (Islam et al., 2016; Sadat and Choi, 2017). In this review, we asked some key questions to understand the current situation of wheat blast in Bangladesh and its future impacts on food and nutritional security of the regions.

The most important question was whether wheat blast spreads to the new areas in Bangladesh and neighbouring countries or not. The first occurrence of wheat blast was limited to the eight districts of Bangladesh during the 2015-6 cropping season (Islam et al., 2016). However, the disease spread to eight more neighbouring districts: Magura, Faridpur and Rajshahi in 2016-7, 2017-8. Although disease re-occurred in the following years in the previously affected districts, its scale of severity was highly reduced, in terms of locations and areas. According to the data of the Department of Agricultural Extension of Bangladesh, total wheat cultivated area in blast affected districts were 99,259 and 47,278 hectares in 2015-16 and 2016-7, respectively (Personal communication with C. K. Das). During 2017-8 season, wheat acreage in Bangladesh stood at 0.349 million hectares which was only $79 \%$ of the previous year and lowest in three decades (https://bit.ly/2Aq0J9b, Last accessed: Aug. 10, 2018). It indicates that wheat cultivated area in the blast affected districts was reduced by $52 \%$ because of government's recommendation to farmers to switch to cultivation of other alternate crops such as boro rice, maize, lentil, etc. instead of wheat, and also due to

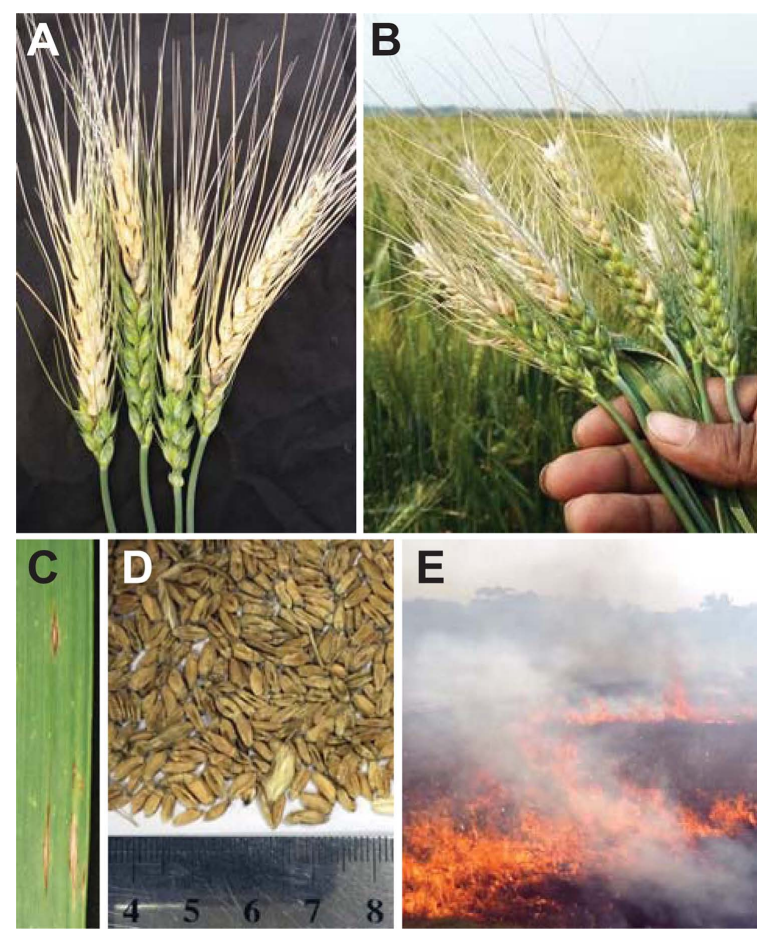

Fig. 2. Symptoms of wheat blast and burning of a wheat blast infected field. (A) Complete bleaching of four wheat spikes above the point of infection collected from a blast infected field of Meherpur in Bangladesh in 2018, (B) Complete bleaching of five wheat spikes above the point of infection collected from a suspected blast infected field of West Bengal in India in 2017 (photo generously provided by Sunita Mahapatra, Bidhan Chandra Krishi Viswavidyalaya, India, (C) Typical eye-shaped lesions and dark gray spots on a severely diseased wheat leaf, (D) Severe blast-affected shriveled and pale wheat seeds cv. Prodip, (E) Clearing of a severely blast affected field of wheat in Chuadanga, Bangladesh by burning (see a video clip at https://www.youtube. com/watch?v=EmL5YM0kIok). 
the fear of farmers who experienced wheat blast in 2015-6 season. The total blast-affected area was also dramatically reduced from 15,442 in 2015-6 to 19.6 hectares in 2016-7. This dramatic decrease in incidence of the disease was not only due to the decrease in area of wheat cultivation but also linked with the drier environment (no rainfall during reproductive stage of wheat). The development of wheat blast disease is favored by higher temperature by higher temperature $\left(18-30^{\circ} \mathrm{C}\right)$ coupled with high humidity (wetting of plants for at least $10 \mathrm{~h}$ due to rain or dew fall) (Cardoso et al., 2008).

Furthermore, intensive inspection, surveillance and management strategies adopted by the government of Bangladesh with international partners also played a role in the decreased spread of disease and crop loss of wheat in the following years after the first devastating emergence of wheat blast. In both cropping seasons (2015-6 and 20167) in Bangladesh, major symptoms associated with wheat blast was completely or partially bleached (dead) spikes (Fig. 2A). Complete or partial bleaching of the spike above the point of infection resulted in no grain or shrivelled grain which ultimately severely affected the yield of wheat (Fig. 2B). In the blast affected plants, typical eye-shaped necrotic lesions with grey centres in the relatively older leaves were also commonly found (Fig. 2C). After the first emergence of the disease, both Bangladesh and Indian government decided to burn the affected crop (Fig. 2D) but burning is not a solution as the disease is spread to a large geographic area where they might be settled on many alternative hosts.

India, the neighbouring country of Bangladesh, is the second largest wheat producer in the world. India is geographically bordered by five severely blast affected districts (hot spots) viz. Kushtia, Meherpur, Chuadanga, Jhenaidah and Jessore of Bangladesh (Islam et al., 2016). In 2016, no occurrence of wheat blast disease was reported in the West Bengal of India (Sadat and Choi, 2017). However, the emergence of wheat blast was observed on about 1,000 hectares of the wheat fields in Murshidabad and Nadia districts of West Bengal in February, 2017 (https://bit. ly/2HtIVcs and https://bit.ly/2AqhedA; Last accessed: Jan. 9 , 2019). Such spread of wheat blast disease to new areas was predicted by the researchers considering the air and seed-borne natures of the blast fungus. Although there is no official report on occurrence of the disease, the Indian government had banned wheat cultivation ('wheat holiday') near the border line $(\sim 2,200 \mathrm{~km})$ and restricted the movement of wheat grains from the infected area (https:// bit.ly/2JcE9nK, Last accessed: Jan. 9, 2019). It seems a good strategy to reduce the inoculum potential for further rapid spread to new wheat cultivation area although the blast fungus has several alternative hosts to establish in a contaminated area.

Taken together, the answer to our first question is that wheat blast is spreading to both inside and outside of Bangladesh. It is now clear that the wheat blast disease is well established in at least one country (Bangladesh) in Asia. Disease occurrence has definitely decreased in quantity, number of location and size of infected area. However, new occurrence of infection observed in the new region indicates loopholes in the control and spread of the wheat blast. Therefore, the financial support of the governments of both Bangladesh and India should continue to promote research and surveillance to mitigate this fearsome disease of this major food crop. The quarantines and surveillance activities should especially be strengthened and keep continuing until the development of an effective management strategy by research against this worrisome plant disease. As this killer of wheat is moving, rapid development of effective management practices including development of blast resistant variety using modern biotechnological approaches including genome editing is needed before it becomes catastrophic. Reduction in funding for disease management and surveillance, if any, can lead to the re-occurrence of wheat blast on a larger scale as the pathogen has already been established in a large area.

Our second question was whether fearsome wheat blast disease can be managed or not. In plant pathology, disease occurs when three factors such as a host, a pathogen, and a favourable environment are in a place. One of the most effective immediate control strategies of the disease may be obtained by not growing wheat in the contaminated districts and nearby areas. However, it seems not a feasible approach for several reasons: (i) $100 \%$ of the farmers may not follow/accept this advice because this issue is related to their livelihood, food habit, and/or family income; (ii) if there is no profitable alternate crop to wheat; (iii) as the pathogen can spread through wind from alternative hosts and contaminated seeds, the chances of outbreak of disease in new areas cannot be ruled out; and (iv) if wheat is a major food crop for the small-holder farmers. To promote this strategy, governments of Bangladesh and India may offer an incentive or subsidy to the farmers to cultivate alternative suitable crops instead of wheat for few years. The government should also suggest suitable alternate crops for blast-contaminated regions and ensure availability of necessary inputs for cultivating those crops. Obviously, such a decision/policy may force to increase wheat import as the country (Bangladesh) has increasing deficit in wheat supply. Since 2015, wheat import in Bangladesh has been increasing sharply, and the country ranks $4^{\text {th }}$ highest wheat 
importer in the world in 2018 (online, 2018). This indicates that the food security about wheat is at stake.

The most important strategy for the mitigation of wheat blast is the development of resistant varieties against wheat blast. Although there is no proven wheat blast resistant commercial variety, however, promising results have been achieved by many researchers during resistance assessment of wheat genotypes/lines against the blast fungus. The cultivars, like Milan, Caninde 1 "S", and BR8 showed considerable resistance against wheat blast (Ha et al., 2016). Another report mentioned that the same cultivar, Milan, is used for breeding programs to produce resistant varieties such as Paragua CIAT, Sausal CIAT, CD 116, Caninde 1, and Milan3/Atila/Cimmyt3 (Kohli et al., 2011; Marangoni et al., 2013). The Wheat Atlas database revealed that some released varieties in India (MACS-6478 and DBW-88), but none in Bangladesh, are based on Milan (http://wheatatlas. org/varieties). In addition, a new variety, BARI Gom 33 (BAW1260), which had shown resistance against wheat blast even in the field assay, was recently developed by the former Wheat Research Centre (WRC) in Bangladesh (Personal Communication with N.C.D. Barma). Other varieties, BRS 201, BRS229, MGS3 Brilhante, and BR24 are also shown to be resistant against wheat blast (Maciel, 2011; Marangoni et al., 2013). Wheat cultivation using those resistant genotype-based varieties will be helpful for preventing the spread of wheat blast in Asia. However, development of a commercial variety through classical breeding obviously takes several (5-10) years.

Researchers have found several resistance genes $(R$ genes) which may enable plants to be resistant to wheat blast pathogens. Although several germplasms and ad- vanced lines displayed high level of resistance against wheat blast in the laboratory and greenhouse environments (Table 1), deployment of them in the field evaluation especially during blast epidemic year in South America was found mostly ineffective. Some $R$ genes were found temperature-sensitive. For example, the wheat cultivar containing $R m g 7$ was not effective against MoT isolate $\mathrm{Br} 47$, when the cultivar was grown at high temperatures such as $26^{\circ} \mathrm{C}$ (Inoue et al., 2017). In addition, the resistance provided by the $2 N S$ translocation had been overcome by aggressive isolate B71. However, there might be hope in the strategy of combining multiple $R$ genes. Wang et al. (2018) recently screened 520 wheat cultivars and found that a cultivar, GR119, was highly resistant to the MoT isolate $\mathrm{Br} 47$. They identified that the resistance was caused by synergistic effect of two $R$ genes, $R m g 8$ and RmgGR 119. Introgression of these two-novel blast resistant genes to the commercial cultivars of wheat may be one of the option for Bangladesh and India. The biggest challenge in development of wheat blast-resistant cultivars through classical breeding is that it requires longer time (5-10 years) and enough blast resistant genetic resources. Therefore, application of genome editing technologies such as CRISPR/Cas9 technique would be useful tools for the development of blast resistant wheat (Haque et al., 2018). It could be done by either stacking of $R$ genes or deletion or disruption of susceptible genes or transcription factors in the genome of a commercial cultivar (Nekrasov et al., 2017; Peng et al., 2017; Wang et al., 2016). The latter approach would result in non-transgenic mutated wheat which could readily be released to the practical application without following strict biosafety guidelines (Haque et al.,

Table 1. The list of resistance genes identified in wheat cultivars

\begin{tabular}{|c|c|c|c|c|}
\hline$R$ genes & Found in & Effective against & Avr genes & References \\
\hline $\operatorname{RmgTd}(t)$ & Triticum dicoccum KU109 (Tat14) & Not to the field isolate & & \\
\hline Rmgl(Rwt4) & Common wheat, Norin 4 (hexaploid) & Avena isolate $\mathrm{Br} 58$ & PWT3, PWT4 & (Takabayashi et al., 2002) \\
\hline Rmg2 & Common wheat, Thatcher & Triticum isolate $\mathrm{Br} 48$ & & (Zhan et al., 2008) \\
\hline Rmg3 & Common wheat, Thatcher & Triticum isolate $\mathrm{Br} 48$ & & (Zhan et al., 2008) \\
\hline Rmg4 & Common wheat, Norin 4 & Digitaria isolate & & (Nga et al., 2009) \\
\hline Rmg5 & Common wheat, Red Egyptian & Digitaria isolate & & (Nga et al., 2009) \\
\hline $\operatorname{Rmg6}(R w t 3)$ & Common wheat, Norin 4 & Lolium isolate TP2 & $P W T 3($ or $A 1)$ & (Vy et al., 2014) \\
\hline Rmg7 & $\begin{array}{l}\text { Triticum dicoccum (tetraploid wheat), } \\
\text { KU112(St17), 120(St24), KU122(St25) }\end{array}$ & Triticum isolate $\mathrm{Br} 48$ & $A V R-R m g 7$ & (Tagle et al., 2015) \\
\hline Rmg8 & Common wheat, S-615 & Triticum isolates $\mathrm{Br} 48$ & $\begin{array}{l}\text { AVR-Rmg8 } \\
(=A V R-R m g 7)\end{array}$ & $\begin{array}{l}\text { (Anh et al., 2015; } \\
\text { Anh et al., 2018) }\end{array}$ \\
\hline $2 N S$ & $\begin{array}{l}\text { chromosomal segment from } \\
\text { Aegilops ventricosa }\end{array}$ & $\begin{array}{l}\text { Triticum isolate } \mathrm{Br} 48 \\
\text { but not } \mathrm{B} 71\end{array}$ & Not identified & (Cruz et al., 2016) \\
\hline RmgGR119 & Albanian wheat accession GR119 & Triticum isolate $\mathrm{Br} 48$ & Not identified & (Wang et al., 2018) \\
\hline
\end{tabular}


2018; Langner et al., 2018). As susceptible genes in wheat have not been well characterized, the characterized orthologous $S$-genes of rice could be targeted for genome editing (Haque et al., 2018). In that case, pleotropic effect may affect the yield of the genome edited wheat. However, mutagenesis of wheat using CRISPR/Cas9 could be a faster approach for development of novel blast resistant wheat. To ease the complication in transformation of wheat, a new targeted mutagenesis in wheat microspores using CRISPR/ Cas9 has recently been established (Bhowmik et al., 2018). A strategy of introducing blast-resistance genes from wild wheat progenitors proposed by Wulff and Dhugga (2018) could also be helpful for rapid development of elite cultivars to confer multilayered disease resistance.

The second factor for disease development is about a pathogen. The wheat blast pathogen belongs to the Magnaporthe oryzae (= Pyricularia oryzae) species complex, which contains several host-specific subgroups. The MoT is distinguished from M. oryzae Oryza pathotype (MoO) in pathogenicity (Kato et al., 2000). MoT develops disease lesions on wheat and Triticum spp. and Aegilop spp., while $\mathrm{MoO}$ did on rice and other grasses. There is no report of host jump of $M$. oryzae from rice to wheat or vice-versa (Maciel et al., 2014). In Bangladesh and India, wheat blast strains (MoT) are now co-occurring with the destructive rice blast $(\mathrm{MoO})$ pathogen in the same areas/land, raising the possibility of genetic exchange between these destructive pathogens. Phylogenomic analyses using 2193 orthologs revealed that wheat blast isolates that caused severe outbreak in 2016 were closely related to the wheat infecting isolates from Brazil (PY0925 and BR32) (Islam et al., 2016). Another analysis using 2,682 orthologs suggested they are closer to the Bolivian strain B71 than the Brazilian isolate PY0925 (Gladieux et al., 2017). A recent sequence analysis revealed that both Bolivian and Bangladesh isolates have the similar genotypic structure (Atc type or allele) in the avirulence gene, PWT3, where multiple transposable elements have been inserted (Inoue et al., 2017). These evidences clearly indicate that the pathogens were not evolved with a host plant in Asian region but they came forcibly from South American countries likely through wheat trade (Ceresini et al., 2018).

Combination of both $R$ genes in a host plant and avirulence $(A v r)$ gene in a pathogen lead to hypersensitive reaction, that is, no disease development in the plant. In case of the PWT3 avirulence gene, M. oryzae Avena pathotype (MoA) contains the PWT3 gene which interacts with the $R w t 3$ gene ( $R$ gene). Avena sativa (oat) doesn't have the $R$ gene, leading to disease development while no disease occurs in Triticum aestivum (wheat) having the Rwt3 gene (Inoue et al., 2017). Inoue et al. (2017) revealed that Bolivian and Bangladesh isolates have the non-functional $P W T 3$ gene and the wheat cultivar having the $R w t 3$ gene is no more helpful in inducing resistance against most MoT strains (Inoue et al., 2017). To introduce an effective $R$ gene into wheat cultivars, its corresponding $A v r$ gene should exist in the MoT population. This is why population genetics for monitoring avirulence genes in the MoT population is important for breeding. Wang et al. (2018) found that $A v r-R m g 8$ gene existed in 15 selected Brazilian isolates and Bangladesh isolate (No. 12), suggesting that introduction of Rmg8 might be effective among most MoT strains (Wang et al., 2018).

The application of chemical fungicide is a cost-effective and easy way to reduce the inoculum size of pathogens. Seed treatments with fungicide will be helpful for eliminating the seed-borne infection. Because wheat blast symptoms appear mainly on the spikes, fungicides combining triazoles with strobilurins have been suggested to control the disease (Kohli et al., 2011). However, development of resistance against fungicides is another challenging issue for chemical control of the disease. The resistance of wheat blast pathogen to strobilurin fungicides (quinoneoutside inhibitors) increased from $36 \%$ of Brazilian populations in 2005 to $90 \%$ in 2012 (Castroagudín et al., 2015). Alternatively, combination of silicon or phosphite with fungicide treatment reduced disease on the spikes (Pagani et al., 2014). Discovery of a more effective fungicide with novel mode of action is warranted. Recently, plant probiotic bacteria isolated from wheat and rice seeds belonging to the genus Bacillus have shown high potential to control wheat blast disease both in vitro and in vivo (Surovy et al., 2017). Considering the eco-friendly nature and rich in biosynthesis of diverse antimicrobial compounds, Bacillus plant probiotic bacteria could be an alternative to the environmentally hazardous synthetic fungicide (Dutta et al., 2018). As M. oryzae is efficient to jump from one grass host to another (Inoue et al., 2017) and can spread through various ways including trade and wind, a reliable and cost-effective diagnostic tool is needed to monitor this pandemic pathogen at the genotype level. Pieck et al. (2017) recently reported a polymerase chain reaction (PCR) assay diagnostic for development of Triticum pathotype specific marker to overcome limitations of ITS primers (Pieck et al., 2017). The assay is based on MoT3 primers from the MGG_02337 gene annotated as a short chain dehydrogenase. $\bar{H}$ owever, a recent study revealed that MoT3 assay could not reliably distinguish between wheat and rice blast isolates from Bangladesh based on DNA amplification experiments (Gupta et al., 2018). Further effort is needed to 
develop a convenient diagnostic tool for detection of wheat blast in suspected seed lot, asymptomatic plant and alternative hosts.

Weather conditions are critical factors for the development of wheat blast disease. Global warming has been found to fuel the occurrence and development of wheat blast disease. Increased temperature correlated to reduction in wheat production at the wheat-cultivating areas (Asseng et al., 2015). Several reports predicted that temperature is rising in Bangladesh, especially during winter season (Hossain and da Silva, 2012). Average winter temperatures were ranged from $18.5 \pm 0.7^{\circ} \mathrm{C}$ in December to $21.0 \pm 0.9^{\circ} \mathrm{C}$ in February in Bangladesh (from 1950 to 1998) (Miah et al., 2014). As winter temperature rises in Bangladesh and India, the productivity of wheat is expected to drop (Asseng et al., 2015). Moreover, because this fungal pathogen favours the temperature ranged from $20^{\circ} \mathrm{C}$ to $30^{\circ} \mathrm{C}$, occurrence of wheat blast will increase, leading to increased yield loss of wheat (Cardoso et al., 2008).

In South America, severe epidemics occurred in the humid and warmer regions like Bolivia, Paraguay and north-eastern Argentina (Kohli et al., 2011). In the northern
Paraná state in Brazil, major outbreaks occurred under the uncommonly humid and warm weather (Farman et al., 2017). In the growth chamber experiment, wheat blast occurred at least 10 hours wet period of spikes (Cardoso et al., 2008). Analysis of weather data collected from the Bangladesh Meteorological Department shows that the temperature rise occurred in all the regions in 2016 mainly due to increase in minimum temperature by $1.8-6.5^{\circ} \mathrm{C}$ compared to 2011-15 (Fig. 3A). Such warming up coupled with rainfall at the flowering time likely contributed to the outbreak of the epidemics in the wheat blast affected districts in Bangladesh. Those regions had rainfall (up to $35 \mathrm{~mm}$ ) with warm temperature $\left(\min .18-23^{\circ} \mathrm{C}\right.$, $\max .21-28^{\circ} \mathrm{C}$ ) in the second and fourth week of February in 2016. The rainfall with subsequent heavy dew in following couple of days likely to kept plants wet enough to be conducive for high sporulation and severe infection. In contrast, wheat blast did not occur in Dinajpur, Rangpur, and many other districts. Those districts had no rainfall although temperature was higher during the heading stage of wheat in 2016. Although heavy dew falls were seen in some areas but almost no rainfall was occurred during the similar growth stage of
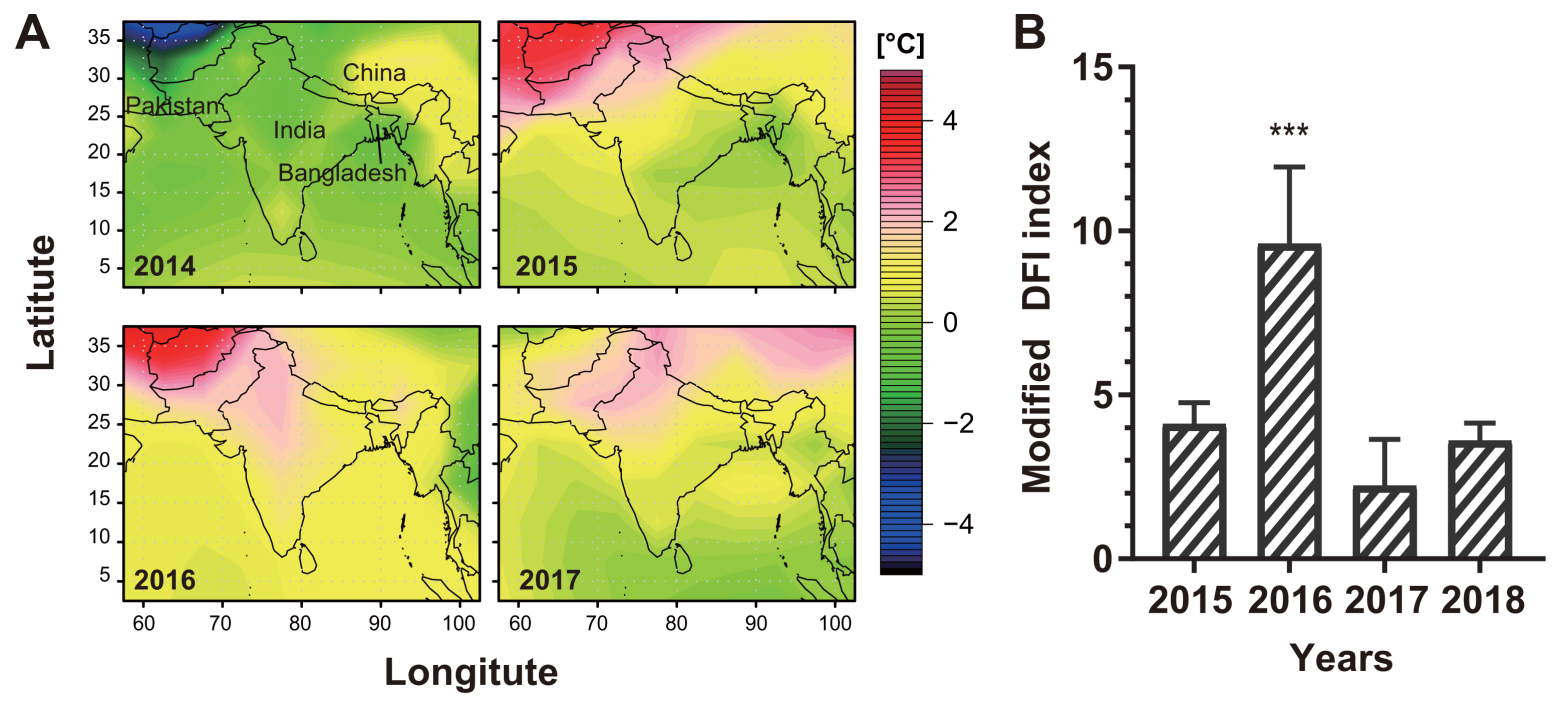

Fig. 3. Effects of climate change on the Bangladesh outbreak of wheat blast in 2016. (A) Temperature anomalies of February from 2014 to 2017 in the India-Bangladesh region. The temperature anomaly indicates a departure of monthly mean temperature from long-term average, and therefore a positive anomaly means that the observed temperature was warmer than the long-term average value. Figures were generated based on the NOAA global surface temperature anomaly dataset, produced by the United States National Center of Environmental Information in 2018 (Smith et al., 2008). (B) Calculation of the modified DFI (day favouring infection) index for the wheat blast-infected regions in 2016. To estimate infection risk for the wheat blast disease, we adopted the DFI index by Fernandes et al. (2017) as an infection risk proxy, which was modified based on the availability of weather variables from the Modern-Era Retrospective Analysis for Research and Applications, version 2 (MERRA-2) climate data (Gelaro et al., 2017). Daily maximum temperature and precipitation variables of the MERRA-2 for 2015-2018 were extracted from eight overlapping grids over the target districts of Bangladesh (latitudes $22^{\circ} 49^{\prime} 43.5468^{\prime \prime}$ N to $24^{\circ} 21^{\prime}$ ' 48.258' $\mathrm{N}$ and longitudes $88^{\circ} 33^{\prime} 29.8224^{\prime \prime}$ 'E to $89^{\circ} 43^{\prime} 42.294^{\prime \prime}$ E), where severe wheat blast epidemics were reported in 2016. The modified DFI index is the number of days with maximum temperature $>23^{\circ} \mathrm{C}$ and rainfall $>0.1 \mathrm{~mm}$ for the period of January to February. 
wheat in 2016-17.

Several prediction models were proposed for wheat blast (Cardoso et al., 2008; Fernandes et al., 2017). The models used climate data such as temperature, relative humidity, rainfall, and solar radiation, and calculated values contributing to development of wheat blast (inoculum potential, spore cloud, and day favouring infection (DFI)). We used the model to calculate DFI of the blast-affected area in Bangladesh from 2015 to 2018 (Farman et al., 2017). The DFI in 2016 was much higher than those in the other years (Fig. 3B), emphasizing the impact of weather on the outbreak. Such prediction based on climate data can be an efficient way to determine times and locations for surveillance and monitoring. In addition, Mottaleb and coworkers used a climate analogue model to find vulnerable regions of wheat blast in Bangladesh, India, and Pakistan (Mottaleb et al., 2018). The authors also used those data to estimate potential economic loss when the disease might occur. Bangladesh and Indian governments can use these prediction models to prepare the national budget for surveillance and control of the wheat blast disease.

What impacts will be on the food security of Bangladesh and India? Consumption of wheat in South Asia has steadily been increasing since the green revolution in 1960s (Mottaleb et al., 2018). As the population of this region is predicted to significantly increase by about $65 \%$ by the year 2050, the demand of staple foods, particularly wheat, must be increased. Bangladesh is one of the good examples for this. Wheat was introduced as an alternative winter crop to meet the food requirements (Hossain and da Silva, 2012) and becomes second major crop (3\% of total cereal consumption) (Sadat and Choi, 2017). While average wheat production per year was 1.15 million MT (metric tonne) for the last decade, the demand for wheat was 5.35 million MT, which is 4.7-fold higher than the supply. The demand increased dramatically especially in last five years and reached 6.68 million MT/year on average. Now Bangladesh becomes the world top five wheat-importing country and its food security for wheat is endangered. Moreover, wheat production is expected to be stuck or reduced for several years because wheat cultivation areas in the blast affected areas were reduced. The recent increase in wheat demand is due to not only the outbreak of wheat blast, but also change in dietary preferences. Prices of mostly imported wheat and wheat flour have increased strongly in recent months (Since July 2017) (http://www.fao.org/giews/countrybrief/country.jsp?code=BGD). According to the Global Information and Early Warning System of FAO, the recent price hike is linked to increased domestic consumption due to option of farmers to boro rice and contraction of wheat planting in blast contaminated districts. Long term plans to meet this requirement should be derived by the Bangladesh government.

India's situation is a little bit different. It has produced sufficient wheat for its domestic consumption for long time. Because the production of the West Bengal state accounts for only $1.24 \%$ of total wheat production of India, yield loss caused by the decreased cultivation would not be serious (http://dwd.dacnet.nic.in/wheat_prod1/area prod.htm). The Indian government's restriction for wheat cultivation in West Bengal was appropriate. However, any further spread of wheat blast into major wheat growing areas in Bangladesh, India and Pakistan could be catastrophic. In Bolivia, wheat production dropped to 37,750 ton in 1999 from 120,414 ton in 1997 (ca. 69\% yield loss) due to severe outbreak of wheat blast (Mottaleb et al., 2018). A recent study indicates that $60 \%$ of wheat producing areas in South Asia are vulnerable to wheat blast infection (Mottaleb et al., 2018). In case of Bangladesh, wheat blast-vulnerable area is $65 \%$ of the wheat cultivated area. It appears from that study that about 7 million hectares of wheat growing areas in Bangladesh, Pakistan and India are still under the threat of blast outbreak. Spread of wheat blast pathogen in those areas causes serious crop loss that results in higher import of wheat to mitigate the increasing demand. The price of wheat will be increased, followed by the reduced purchasing capacity of the people which can ultimately affect the food and nutritional security in the entire region.

Breeding a resistant cultivar is an urgent need. Breeders should take into account of resistance to blast in addition to rust or blight. Unfortunately, strong resistance to one disease (e.g. wheat blast) might cause strong susceptibility to another disease (e.g. Fusarium head blight) (Ha et al., 2016). Resistant cultivar might lose high yield or good taste. For example, in Bolivia, moderately susceptible cultivar, Motacu, was preferred over the Milan genotypebased resistant cultivar, Sausal (Vales et al., 2018). This is because farmers wanted other traits that Motacu has such as drought tolerance and resistance to rust and blight. Novel approaches such as genome editing for blast resistant wheat or biological control of wheat blast by plant probiotics are needed. As the Bangladesh government seems technology-friendly and favours the application of advanced biotechnology (e.g., GM technology) in agriculture, either mutagenesis of wheat using CRISPR/Cas9 genome editing or stacking of wheat blast resistant genes would have the excellent chance of halting the spread of the pathogen in South Asia (Wulff and Dhugga, 2018). Another concern is the obvious genome evolution of the imported MoT in South Asia which may complicate its 
future management. Continuous monitoring is required to understand genetics of MoT population in Bangladesh and India. Therefore, development of a convenient molecular diagnostic tool is needed for monitoring and surveillance of wheat blast. Now again we realized disease outbreak is not only a problem in one country but also a global issue for all the residents on earth. Physical border line has no meaning for microbial pathogens. For a rapid mitigation of this new enemy of a major food crop, a concerted global effort is needed through practicing open data sharing and open science approaches. In addition, both short and longterm research plans to counteract the wheat blast should be formulated by the national governments and the global research communities.

\section{Acknowledgements}

This work was supported by the Incheon National University Research Grant in 2014.

\section{References}

Anh, V. L., Anh, N. T., Tagle, A. G., Vy, T. T. P., Inoue, Y., Takumi, S., Chuma, I. and Tosa, Y. 2015. Rmg8, a new gene for resistance to Triticum isolates of Pyricularia oryzae in hexaploid wheat. Phytopathology 105:1568-1572.

Anh, V. L., Inoue, Y., Asuke, S., Vy, T. T. P., Anh, N. T., Wang, S., Chuma, I. and Tosa, Y. 2018. Rmg8 and Rmg7, wheat genes for resistance to the wheat blast fungus, recognize the same avirulence gene AVR-Rmg8. Mol. Plant Pathol. 19:12521256.

Asseng, S., Ewert, F., Martre, P., Rötter, R. P., Lobell, D. B., Cammarano, D., Kimball, B. A., Ottman, M. J., Wall, G. W., White, J. W., Reynolds, M. P., Alderman, P. D., Prasad, P. V. V., Aggarwal, P. K., Anothai, J., Basso, B., Biernath, C., Challinor, A. J., De Sanctis, G., Doltra, J., Fereres, E., Garcia-Vila, M., Gayler, S., Hoogenboom, G., Hunt, L. A., Izaurralde, R. C., Jabloun, M., Jones, C. D., Kersebaum, K. C., Koehler, A. K., Müller, C., Kumar, S. N., Nendel, C., O'Leary, G., Olesen, J. E., Palosuo, T., Priesack, E., Rezaei, E. E., Ruane, A. C., Semenov, M. A., Shcherbak, I., Stöckle, C., Stratonovitch, P., Streck, T., Supit, I., Tao, F., Thorburn, P. J., Waha, K., Wang, E., Wallach, D., Wolf, J., Zhao, Z. and Zhu, Y. 2015. Rising temperatures reduce global wheat production. Nat. Clim. Change 5:143-147.

Bhowmik, P., Ellison, E., Polley, B., Bollina, V., Kulkarni, M., Ghanbarnia, K., Song, H., Gao, C., Voytas, D. F. and Kagale, S. 2018. Targeted mutagenesis in wheat microspores using CRISPR/Cas9. Sci. Rep. 8:6502.

Callaway, E. 2016. Devastating wheat fungus appears in Asia for first time. Nature 532:421-422.

Cardoso, C. A. d. A., Reis, E. M. and Moreira, E. N. 2008. De- velopment of a warning system for wheat blast caused by Pyricularia grisea. Summa Phytopathol. 34:216-221.

Castroagudín, V. L., Ceresini, P. C., de Oliveira, S. C., Reges, J. T., Maciel, J. L., Bonato, A. L., Dorigan, A. F. and McDonald, B. A. 2015. Resistance to QoI fungicides is widespread in Brazilian populations of the wheat blast pathogen Magnaporthe oryzae. Phytopathology 105:284-294.

Ceresini, P. C., Castroagudín, V. L., Rodrigues, F. Á., Rios, J. A., Eduardo Aucique-Pérez, C., Moreira, S. I., Alves, E., Croll, D. and Maciel, J. L. N. 2018. Wheat blast: past, present, and future. Annu. Rev. Phytopathol. 56:427-256.

Cruz, C. D., Peterson, G. L., Bockus, W. W., Kankanala, P., Dubcovsky, J., Jordan, K. W., Akhunov, E., Chumley, F., Baldelomar, F. D. and Valent, B. 2016. The 2NS translocation from aegilops ventricosa confers resistance to the triticum pathotype of Magnaporthe oryzae. Crop Sci. 56:990-1000.

Dutta, S., Surovy, M. Z., Gupta, D. R., Mahmud, N. U., Chanclud, E., Win, J., Kamoun, S. and Islam, T. 2018. Genomic analyses reveal that biocontrol of wheat blast by Bacillus spp. may be linked with production of antimicrobial compounds and induced systemic resistance in host plants. Figshare doi: 10.6084/m9.figshare.5852661.v1.

Farman, M., Peterson, G., Chen, L., Starnes, J., Valent, B., Bachi, P., Murdock, L., Hershman, D., Pedley, K., Fernandes, J. M. and Bavaresco, J. 2017. The Lolium pathotype of Magnaporthe oryzae recovered from a single blasted wheat plant in the United States. Plant Dis. 101:684-692.

Fernandes, J. M. C., Nicolau, M., Pavan, W., Hölbig, C. A., Karrei, M., de Vargas, F., Bavaresco, J. L. B., Lazzaretti, A. T. and Tsukahara, R. Y. 2017. A weather-based model for predicting early season inoculum build-up and spike infection by the wheat blast pathogen. Trop. Plant Pathol. 42:230-237.

Fisher, M. C., Henk, D. A., Briggs, C. J., Brownstein, J. S., Madoff, L. C., McCraw, S. L. and Gurr, S. J. 2012. Emerging fungal threats to animal, plant and ecosystem health. Nature 484:186-194.

Gelaro, R., McCarty, W., Suárez, M. J., Todling, R., Molod, A., Takacs, L., Randles, C. A., Darmenov, A., Bosilovich, M. G., Reichle, R., Wargan, K., Coy, L., Cullather, R., Draper, C., Akella, S., Buchard, V., Conaty, A., da Silva, A. M., Gu, W., Kim, G., Koster, R., Lucchesi, R., Merkova, D., Nielsen, J. E., Partyka, G., Pawson, S., Putman, W., Rienecker, M., Schubert, S. D., Sienkiewicz, M. and Zhao, B. 2017. The modern-era retrospective analysis for research and applications, version 2 (MERRA-2). J. Clim. 30:5419-5454.

Gladieux, P., Condon, B., Ravel, S., Soanes, D., Maciel, J. L. N., Nhani, A., Chen, L., Terauchi, R., Lebrun, M. H., Tharreau, D., Mitchell, T., Pedley, K. F., Valent, B., Talbot, N. J., Farman, M. and Fournier, E. 2017. Gene flow between divergent cerealand grass-specific lineages of the rice blast fungus Magnaporthe oryzae. mBio 9:e01219-01217.

Gupta, D. R., Avila, C. S. R., Win, J., Soanes, D. M., Ryder, L. S., Croll, D., Bhattacharjee, P., Hossain, M. S., Mahmud, N. U., Mehbub, M. S., Surovy, M. Z., Talbot, N. J., Kamoun, S. 
and Islam, M. T. 2018. The MoT3 assay does not distinguish between Magnaporthe oryzae wheat and rice blast isolates from Bangladesh. Phytopathology doi: 10.1094/PHYTO-0618-0199-LE. (in Press)

Ha, X., Koopmann, B. and von Tiedemann, A. 2016. Wheat blast and Fusarium head blight display contrasting interaction patterns on ears of wheat genotypes differing in resistance. Phytopathology 106:270-281.

Haque, E., Taniguchi, H., Hassan, M. M., Bhowmik, P., Karim, M. R., Śmiech, M., Zhao, K., Rahman, M. and Islam, T. 2018. Application of CRISPR/Cas9 genome editing technology for the improvement of crops cultivated in tropical climates: Recent progress, prospects, and challenges. Front. Plant Sci. 9:617.

Hossain, A. and da Silva, J. A. T. 2012. Wheat production in Bangladesh: its future in the light of global warming. AoB. Plants 5:pls042.

Igarashi, S., Utiamada, C. M., Igarashi, L. C., Kazuma, A. H. and Lopes, R. S. 1986. Pyricularia em trigo. 1. Ocorrencia de Pyricularia sp. no estado do Parana. Fitopatol. Bras. 11:351352 (in Português).

Inoue, Y., Vy, T. T. P., Yoshida, K., Asano, H., Mitsuoka, C., Asuke, S., Anh, V. L., Cumagun, C. J. R., Chuma, I., Terauchi, R., Kato, K., Mitchell, T., Valent, B., Farman, M. and Tosa, Y. 2017. Evolution of the wheat blast fungus through functional losses in a host specificity determinant. Science 357:80-83.

Islam, M. T., Croll, D., Gladieux, P., Soanes, D. M., Persoons, A., Bhattacharjee, P., Hossain, M. S., Gupta, D. R., Rahman, M. M., Mahboob, M. G., Cook, N., Salam, M. U., Surovy, M. Z., Sancho, V. B., Maciel, J. L. N., NhaniJúnior, A., Castroagudín, V. L., de Assis Reges, J. T., Ceresini, P. C., Ravel, S., Kellner, R., Fournier, E., Tharreau, D., Lebrun, M. H., McDonald, B. A., Stitt, T., Swan, D., Talbot, N. J., Saunders, D. G. O., Win, J. and Kamoun, S. 2016. Emergence of wheat blast in Bangladesh was caused by a South American lineage of Magnaporthe oryzae. BMC Biol. 14:84.

Kato, H., Yamamoto, M., Yamaguchi-Ozaki, T., Kadouchi, H., Iwamoto, Y., Nakayashiki, H., Tosa, Y., Mayama, S. and Mori, N. 2000. Pathogenicity, mating ability and DNA restriction fragment length polymorphisms of Pyricularia populations isolated from Gramineae, Bambusideae and Zingiberaceae plants. J. Gen. Plant Pathol. 66:30-47.

Kohli, M. M., Mehta, Y. R., Guzman, E., De Viedma, L. and Cubilla, L. E. 2011. Pyricularia blast - a threat to wheat cultivation. Czech J. Genet. Plant. Breed. 47:S130-S134.

Langner, T., Kamoun, S. and Belhaj, K. 2018. CRISPR crops: Plant genome editing toward disease resistance. Annu. Rev. Phytopathol. 56:479-512.

Maciel, J. L. 2011. Magnaporthe oryzae, the blast pathogen: current status and options for its control. CAB Rev. 6:1-8.

Maciel, J. L., Ceresini, P. C., Castroagudín, V. L., Zala, M., Kema, G. H. and McDonald, B. A. 2014. Population structure and pathotype diversity of the wheat blast pathogen Magnaporthe oryzae 25 years after its emergence in Brazil. Phytopathology 104:95-107.

Malaker, P. K., Barma, N. C. D., Tiwari, T. P., Collis, W. J., Duveiller, E., Singh, P. K., Joshi, A. K., Singh, R. P., Braun, H.J., Peterson, G. L., Pedley, K. F., Farman, M. L. and Valent, B. 2016. First report of wheat blast caused by Magnaporthe oryzae pathotype triticum in Bangladesh. Plant Dis. 100:2330.

Marangoni, M. S., Nunes, M. P., Fonseca, N. and Mehta, Y. R. 2013. Pyricularia blast on white oats - a new threat to wheat cultivation. Trop. Plant Pathol. 38:198-202.

Miah, M. A. M., Haque, A. K. E. and Hossain, S. 2014. Economic impact of climate change on wheat productivity in Bangladesh: A Ricardian approach. In: Science, Policy and Politics of Modern Agricultural System, eds. by M. Behnassi, S. A. Shahid and N. Mintz-Habib, pp. 97-108. Springer, Dordrecht, Nederland.

Mottaleb, K. A., Singh, P. K., Sonder, K., Kruseman, G., Tiwari, T. P., Barma, N. C. D., Malaker, P. K., Braun, H. J. and Erenstein, O. 2018. Threat of wheat blast to South Asia's food security: An ex-ante analysis. PLoS One 13:e0197555.

Nekrasov, V., Wang, C., Win, J., Lanz, C., Weigel, D. and Kamoun, S. 2017. Rapid generation of a transgene-free powdery mildew resistant tomato by genome deletion. Sci. Rep. 7:482.

Nga, N., Hau, V. T. and Tosa, Y. 2009. Identification of genes for resistance to a Digitaria isolate of Magnaporthe grisea in common wheat cultivars. Genome 52:801-809.

Pagani, A. P. S., Dianese, A. C. and Café-Filho, A. C. 2014. Management of wheat blast with synthetic fungicides, partial resistance and silicate and phosphite minerals. Phytoparasitica 42:609-617.

Peng, A. H., Chen, S. C., Lei, T. G., Xu, L. Z., He, Y. R., Wu, L., Yao, L. X. and Zou, X. P. 2017. Engineering canker-resistant plants through CRISPR/Cas9-targeted editing of the susceptibility gene CsLOB1 promoter in citrus. Plant Biotechnol. J. 15:1509-1519.

Pennisi, E. 2010. Armed and dangerous. Science 327:804-805.

Pieck, M. L., Ruck, A., Farman, M. L., Peterson, G. L., Stack, J. P., Valent, B. and Pedley, K. F. 2017. Genomics-based marker discovery and diagnostic assay development for wheat blast. Plant Dis. 101:103-109.

Sadat, M. A. and Choi, J. 2017. Wheat blast: A new fungal inhabitant to Bangladesh threatening world wheat production. Plant Pathol. J. 33:103-108.

Smith, T. M., Reynolds, R. W., Peterson, T. C. and Lawrimore, J. 2008. Improvements to NOAA's historical merged landocean surface temperature analysis (1880-2006). J. Clim. 21:2283-2296.

Surovy, M. Z., Gupta, D. R., Chanclud, E., Win, J., Kamoun, S. and Islam, T. 2017. Plant probiotic bacteria suppress wheat blast fungus Magnaporthe oryzae Triticum pathotype. Figshare doi: 10.6084/m9.figshare.5549278.v1.

Tagle, A. G., Chuma, I. and Tosa, Y. 2015. Rmg7, a new gene for resistance to Triticum isolates of Pyricularia oryzae identified in tetraploid wheat. Phytopathology 105:495-499. 
Takabayashi, N., Tosa, Y., Oh, H. S. and Mayama, S. 2002. A gene-for-gene relationship underlying the species-specific parasitism of Avena/Triticum isolates of Magnaporthe grisea on wheat cultivars. Phytopathology 92:1182-1188.

Vales, M., Anzoátegui, T., Huallpa, B. and Cazon, M. I. 2018. Review on resistance to wheat blast disease (Magnaporthe oryzae Triticum) from the breeder point-of-view: use of the experience on resistance to rice blast disease. Euphytica 214:1.

Vy, T. T. P., Hyon, G.-S., Nga, N. T. T., Inoue, Y., Chuma, I. and Tosa, Y. 2014. Genetic analysis of host-pathogen incompatibility between Lolium isolates of Pyricularia oryzae and wheat. J. Gen. Plant Pathol. 80:59-65.

Wang, F. J., Wang, C. L., Liu, P. Q., Lei, C. L., Hao, W., Gao,
Y., Liu, Y. G. and Zhao, K. J. 2016. Enhanced rice blast resistance by CRISPR/Cas9-targeted mutagenesis of the ERF transcription factor gene OsERF922. PLoS One 11:e0154027.

Wang, S., Asuke, S., Vy, T. T. P., Inoue, Y., Chuma, I., Win, J., Kato, K. and Tosa, Y. 2018. A new resistance gene in combination with $R m g 8$ confers strong resistance against Triticum isolates of Pyricularia oryzae in a common wheat landrace. Phytopathology 108:1299-1306.

Wulff, B. B. H. and Dhugga, K. S. 2018. Wheat-the cereal abandoned by GM. Science 361:451-452.

Zhan, S., Mayama, S. and Tosa, Y. 2008. Identification of two genes for resistance to Triticum isolates of Magnaporthe oryzae in wheat. Genome 51:216-221. 